\title{
Alternative treatment to stimulate the germination of recently harvested wheat seeds ${ }^{1}$
}

\author{
Tereza Cristina de Carvalho ${ }^{2 *}$, Osvaldo de Castro Ohlson ${ }^{3}$, Maristela Panobianco ${ }^{4}$
}

\begin{abstract}
The germination test for recently harvested wheat seeds requires a period of up to 20 days, because of the presence of dormancy. The possibility of reducing this period provides greater speed to the allocation of seeds, as well as an increased operational capacity of analytical laboratories. This study aimed at evaluating the effectiveness of treatments to stimulate the germination of recently harvested wheat seeds, reducing the five-day pre-cheeling period recommended to run the test. Seeds from various wheat genotypes were used: BRS Guamirim, BRS Tangará, BRS Pardela, CD 108, CD 116, CD 150, IPR Catuara TM, Frontana, IPR Taquari, Safira and Quartzo. They were analyzed immediately after collection and then stored for 30 and 180 days. In each evaluation period (immediately after harvesting, 30 and 180 days of storage), the determination of water content, the germination test (seeds without pre-chilling and pre-chilling between 5 and $10^{\circ} \mathrm{C}$ for three to five days), and also the tetrazolium test to quantify viability and seed dormancy were carried out. Based on these results, it is concluded that there is effectiveness in overcoming wheat seed dormancy, adopting the pre-cheeling procedure between 5 and $10^{\circ} \mathrm{C}$ for three days.
\end{abstract}

Index terms: Triticum aestivum, physiological quality, dormancy overcoming.

\section{Tratamento alternativo para estimular a germinação de sementes recém-colhidas de trigo}

RESUMO - O teste de germinação para sementes recém-colhidas de trigo demanda um período de até 20 dias, em virtude da presença de dormência. A possibilidade de redução deste período, proporciona maior rapidez quanto ao destino das sementes, bem com o aumento da capacidade operacional dos laboratórios de análise. Objetivou-se avaliar a eficiência de tratamentos para estimular a germinação de sementes recém-colhidas de trigo, reduzindo-se o período de cinco dias de pré-esfriamento recomendado para a condução do teste. Utilizaram-se sementes de vários genótipos de trigo: BRS Guamirim, BRS Tangará, BRS Pardela, CD 108, CD 116, CD 150, IPR Catuara TM, Frontana, IPR Taquari, Safira e Quartzo, analisadas logo após a colheita e depois de armazenadas por 30 e 180 dias. Em cada época de avaliação (logo após a colheita, 30 e 180 dias de armazenamento), realizaram-se a determinação do teor de água, teste de germinação (em sementes sem pré-esfriamento e com pré-esfriamento entre 5 e $10^{\circ} \mathrm{C}$ por três e por cinco dias), e também realizou-se em cada época de avaliação, o teste de tetrazólio para quantificar a viabilidade e dormência das sementes. Com base nos resultados obtidos, conclui-se que há eficiência na superação da dormência de sementes de trigo, adotando-se o procedimento de pré-esfriamento entre 5 e $10{ }^{\circ} \mathrm{C}$ por três dias.

Termos para indexação: Triticum aestivum, qualidade fisiológica, quebra de dormência.

\section{Introduction}

Wheat (Triticum aestivum) is one of the most important cereals (Kiss, 2011; Punder and Pruimboom, 2013), with a world production in the 2015/2016 harvest of approximately 710 million tons. In Brasil, the biggest producing region is the South, represented by Paraná, Santa Catarina and Rio Grande

${ }^{1}$ Submitted on 07/06/2016. Accepted for publication on 08/29/2016. ${ }^{2}$ Centro de Ensino Superior de Campos Gerais, CESCAGE, 84010-050 Ponta Grossa, PR, Brasil.

${ }^{3}$ Empresa Paranaense de Classificação de Produtos, Laboratório de Análise de Sementes de Curitiba, 80035-060 - Curitiba, PR, Brasil. do Sul states, with a production of 7.2 million tons, more than $90 \%$ of the national production (Conab, 2016).

Brazil has a solid position as one of the greatest world grain producers, and this production increase is associated to technological progresses, management and producers' efficiency. The estimate for the 2016/16 harvest is that wheat culture will increase its production by $11.4 \%$, compared to the

\footnotetext{
${ }^{4}$ Departamento de Fitotecnia e Fitossanitarismo, Universidade Federal do Paraná, 80035-050 - Curitiba, PR, Brasil.

*Corresponding author < tcdcarva@gmail.com >
} 
previous one, even with the prediction of a $9.8 \%$ reduction of the cultivated area, occupying 2.48 million hectares (Conab, 2015); this increases the work routine in seed analysis laboratories.

In order to evaluate the viability of seeds, laboratories perform germination tests on paper towel, which provide highly reliable results (Brasil, 2009; Kataoka et al., 2011; Elias et al., 2015). However, when performed on recently harvested wheat seeds, values do not generally relate to the ones obtained during pre-seeding. This occurs because many wheat genotypes present dormant seeds right after harvesting, in variable intensities (Gavazza et al., 2012; Gao and Ayele, 2014).

Wheat seeds present non-integumentary dormancy, that is, associated to physiological and internal factors (Gao and Ayele, 2014; Marcos-Filho, 2015). In the physiological dormancy, the embryo, despite being physically complete, does not resume its growth after reaching its physiological maturity, especially because of factors related to hormonal balance or to the presence of inhibiting chemical compounds (Liu et al., 2013; Gao and Ayele, 2014; Nonokagi, 2014); it is important to highlight that dormancy is considered a genetically desirable attribute in commercialized wheat genotypes, and that it presents high heritability in segregant populations, that is, it is transmitted to descendents ( $\mathrm{Gu}$ et al., 2010; Tunes et al., 2011; Gavazza et al., 2012) since these genotypes do not present viviparity. Overcoming dormancy in these seeds involves hormonal changes in the embryo, such as the increase in germination promoter concentrations (Tunes et al., 2011; Marcos-Filho, 2015). Such hormonal change may be obtained, according to the Rules for Seed Testing (Brasil, 2009), by exposing seeds to pre-chilling at a $5-10{ }^{\circ} \mathrm{C}$ temperature for five days.

In seed analysis laboratories, germination evaluation is a standard procedure; it has to be conducted according to the recommendations from the Rules for Seed Testing (Brasil, 2009). However, the determination of wheat seed germination power may take up to 20 days; eight days is the prescribed maximum test duration, plus five days to perform dormancy overcoming (prechilling between 5 and $10^{\circ} \mathrm{C}$ ) and seven more days if there are still non-germinated seeds (Brasil, 2009).

Besides this, it is necessary to consider that these five days for dormancy overcoming frequently generate another problem, that is, the reduction of the period to implement the germination test, providing only three weekdays (Wednesday, Thursday and Friday), in case the laboratory does not work on Saturday and Sunday, which significantly reduces the operational capacity. In addition, 20 days for a test is a relatively long period when one needs results to make a quick decision on the quality of seeds.

Thus, a higher agility to evaluate the germination power of dormant wheat seeds, with guaranteed efficiency, becomes a desirable proposal in laboratories. Therefore, the goal of this work was to evaluate the effectiveness of treatments stimulating the germination of recently harvested wheat seeds, with the reduction of the five-day pre-chilling period, currently recommended for this test.

\section{Material and Methods}

The research was conducted with wheat seeds from the cultivars: BRS Guamirim, BRS Tangará, BRS Pardela, CD 108, CD 116, CD 150, IPR Catuara TM, Frontana, IPR Taquari, Safira and Quartzo; each genotype was represented by a lot. At first, seeds from each lot were homogenized in a centrifugal divider, based on the criteria established in the Rules for Seed Testing (Brasil, 2009). Subsequently, they were placed in Kraft paper bags and stored in a controlled environment $\left(14{ }^{\circ} \mathrm{C}\right.$ and $60 \%$ relative air humidity) during all the experiment period.

The analysis of seed viability was performed right after harvesting, in order to obtain a higher percentage of dormant seeds, after storing them for 30 and 180 days.

The used tests are described as follows.

Determination of water content: determined by the method oven at $105 \pm 3{ }^{\circ} \mathrm{C}$ for 24 hours, with two subsamples for each one of the eight replications per genotype (Brasil, 2009). Results were expressed in percentage on a wet basis.

Germination test: for each cultivar, eight replications of 50 seeds were distributed on paper towel rolls moistened with a water quantity equal to 2.5 times the dry substrate mass, and kept in germinator at $20{ }^{\circ} \mathrm{C}$ under constant light. Normal seedling counting was performed on the fifth day after seeding, based on the criteria established in the Rules for Seed Testing (Brasil, 2009). Results were expressed in normal seedling percentage.

Dormancy overcoming: for each genotype, the germination test was set up as described before. However, before seeds were kept in the germinator, paper towel rolls were exposed to two periods of pre-chilling between 5 and $10{ }^{\circ} \mathrm{C}$, three days of incubation (alternative procedure) and five days (traditionally recommended in Brasil - 2009) in addition to the treatment without the exposure to pre-chilling. After each period, seeds were transferred to a germinator at $20{ }^{\circ} \mathrm{C}$ and analyzed according to criteria established by the Rules for Seed Testing (Brasil, 2009). Results were expressed in average percentage of normal seedlings for each lot.

Intact and swollen seed at the end of the test period were submitted to viability evaluation by tetrazolium test, described as follows, in order to confirm dormancy. 
Tetrazolium test - viability in order to perform it, the methodology proposed by Carvalho et al. (2012) was followed, cutting seeds in longitudinal bi-sections along the embryo and the endosperm and placing one seed half in $3 \mathrm{~mL}$ of $0.075 \%$ solution of 2,3,5-triphenyltetrazolium chloride, in a plastic cup (50 mL capacity), at $40{ }^{\circ} \mathrm{C}$ in the dark, for 2 hours. After that, seeds were individually evaluated and separated into feasible and non-feasible, as proposed by Carvalho et al. (2012), to confirm wheat seed viability or not.

Data obtained from each test, except for the determination of water content, were analyzed according to the Completely Randomized Design (CRD), with eight replications, separately for each conducted test, singularly evaluating the periods of chilling and storage of seeds. Since the goal was comparing the effectiveness of an alternative method to overcome dormancy among cultivars (qualitative factor) that presented seed dormancy, the comparison among averages was used for the analyzed genotypes. The analysis was performed with no data transformation, using the statistical program ASSISTAT, version 7.7 beta (Silva, 2016). Averages were compared with the Scott-Knott test $(\mathrm{p} \leq 0.01)$.

\section{Results and Discussion}

With data about seed water content (Table 1), it was possible to verify that the 11 genotypes presented similar values; this is an important fact to run the test (MarcosFilho, 2015). When wheat seeds reach their physiological maturity, they contain approximately $30.0 \%$ water and, from this moment on, by a natural process, they start to dehydrate with variable intensity, according to the environment. During seed harvesting, the water content of the obtained seed samples was analyzed, and water content values varied between 12.6 and $13.8 \%$. The moisture content of the seeds was followed during storage period, and remained between 11.9 and $13.3 \%$ after 30 days of storage; after 180 days of storage, they maintained between 10.5 and $12.8 \%$ water content.

The germination percentage (Table 2) after seed harvesting for CD 108, Frontana, IPR Taquari, Safira and Quartzo cultivars' was lower than the allowed to sell wheat seeds, that is, $80 \%$; this value was established by Normative Ruling n. 45 (IN 45/2013). However, when verifying the viability values obtained in the tetrazolium test (Table 2), it was possible to notice much higher values for the same genotypes, reaching 82 to $94 \%$, which indicated the presence of dormant seeds. With these high viability values, it is possible to deduce that the low germination obtained right after harvesting was due to the presence of dormant seeds, since no procedure to overcome the dormancy of these seeds was adopted. It is important to highlight that, after storing seeds in an environment with low relative humidity, the difference in results from the two tests (germination and tetrazolium) was generally lower (Table 2).

Table 1. Water content (\%) of seeds from various wheat genotypes, obtained right after harvesting and after 30 and 180 days of seed storage.

\begin{tabular}{lccc}
\hline \multirow{2}{*}{ Genotypes } & \multicolumn{3}{c}{ Water content of seeds (\%) } \\
\cline { 2 - 4 } & $\begin{array}{c}\text { Recently } \\
\text { harvested }\end{array}$ & $\begin{array}{c}\text { After 30 days } \\
\text { of storage }\end{array}$ & $\begin{array}{c}\text { After 180 days } \\
\text { of storage }\end{array}$ \\
\hline BRS Tangará & $\ldots \ldots \ldots \ldots \ldots \ldots \ldots \ldots \ldots \ldots \ldots \ldots \ldots \ldots \ldots \ldots \ldots \ldots \ldots \ldots \ldots \ldots \ldots \ldots \ldots \ldots \ldots \ldots \ldots \ldots \ldots \ldots \ldots \ldots \ldots \ldots \ldots \ldots \ldots \ldots \ldots \ldots \ldots \ldots \ldots$ \\
Catuará & 13.2 & 12.6 & 12.0 \\
CD 108 & 12.9 & 12.8 & 11.9 \\
CD 116 & 13.0 & 13.3 & 12.8 \\
CD 150 & 13.6 & 12.3 & 12.0 \\
Guamirim & 12.8 & 13.0 & 10.9 \\
Pardela & 12.8 & 13.0 & 11.3 \\
Frontana & 13.6 & 12.8 & 11.9 \\
IPR Taquari & 13.8 & 12.9 & 12.2 \\
Safira & 13.0 & 12.4 & 11.6 \\
Quartzo & 12.8 & 12.0 & 11.8 \\
\hline & 12.6 & 11.9 & 10.5 \\
\hline
\end{tabular}

In wheat and other winter cereal seeds, it is common to find dormant seeds, because of the presence of substances that inhibit the alpha-amylase enzyme; these substances will delay reserve degradation (Taiz and Zeiger, 2013).

As for recently harvested seeds, after they were submitted to dormancy overcoming treatments (three and five days of pre-chilling at $5-10^{\circ} \mathrm{C}$ ), high values of normal seedlings were obtained (Table 3 ).

The tetrazolium test allows evaluating the viability of wheat seeds, even if they are dormant (Carvalho et al., 2012); thus, higher germination values were expected, since the tested genotypes presented, in general, dormant seeds (Table 4). It is also possible to verify that cultivars with the lowest germination percentage, that is, Frontana, IPR Taquari, Safira and Quartzo (Table 2), are the ones presenting the highest number of dormant seeds (Table 4).

It is known that many wheat genotypes are dormant (Bojovic, 2010; Gu et al., 2010; Tunes et al., 2011; Gavazza et al., 2012; Liu et al., 2013; Gao and Ayele, 2014), and this behavior may hide information on the presence of feasible seeds in the germination test. In this sense, firms created procedures that allow overcoming 
the dormancy of recently harvested seeds, obtaining reliable information about the germination potential. The prescription of Rules for Seed Testing (Brasil, 2009) is clear about the five-day pre-chilling period in order to overcome dormancy. However, it is possible to reduce it to three days, according to the results presented in Table 4. Values obtained from dormant seeds among cultivars (with three days of pre-chilling) are really similar to the ones with five pre-chilling days.

Table 2. Germination (\%) and viability (\%) by tetrazolium test for various wheat genotypes, obtained right after harvesting and after 30 and 180 days of seed storage.

\begin{tabular}{|c|c|c|c|c|c|c|}
\hline \multirow{3}{*}{ Genotypes } & \multirow{2}{*}{\multicolumn{2}{|c|}{ Recently harvested seeds }} & \multicolumn{4}{|c|}{ After storage } \\
\hline & & & \multicolumn{2}{|c|}{30 days } & \multicolumn{2}{|c|}{180 days } \\
\hline & Germination & Viability & Germination & Viability & Germination & Viability \\
\hline \multicolumn{7}{|c|}{ 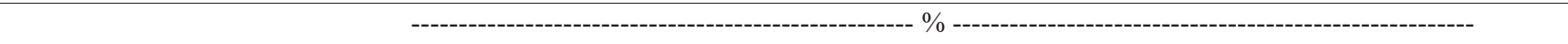 } \\
\hline BRS Tangará & $81 \mathrm{a}$ & $85 \mathrm{~b}$ & $83 \mathrm{c}$ & $86 \mathrm{~b}$ & $84 \mathrm{~b}$ & $87 \mathrm{~b}$ \\
\hline Catuará & $83 \mathrm{a}$ & $85 \mathrm{~b}$ & $88 \mathrm{~b}$ & $86 \mathrm{~b}$ & $90 \mathrm{~b}$ & $86 \mathrm{~b}$ \\
\hline CD 108 & $77 \mathrm{~b}$ & $82 \mathrm{~b}$ & $78 \mathrm{~d}$ & $81 \mathrm{c}$ & $82 \mathrm{c}$ & $81 \mathrm{c}$ \\
\hline CD 116 & $84 \mathrm{a}$ & $90 \mathrm{a}$ & $92 \mathrm{a}$ & $91 \mathrm{a}$ & $92 \mathrm{a}$ & $91 \mathrm{a}$ \\
\hline CD 150 & $81 \mathrm{a}$ & $84 \mathrm{~b}$ & $87 \mathrm{~b}$ & $84 \mathrm{~b}$ & $90 \mathrm{~b}$ & $85 \mathrm{~b}$ \\
\hline Guamirim & $83 \mathrm{a}$ & $88 \mathrm{a}$ & $90 \mathrm{~b}$ & $89 a$ & $92 \mathrm{a}$ & $88 \mathrm{~b}$ \\
\hline Pardela & $85 \mathrm{a}$ & $88 \mathrm{a}$ & $91 \mathrm{a}$ & 89 a & $92 \mathrm{a}$ & $88 \mathrm{~b}$ \\
\hline Frontana & $76 \mathrm{~b}$ & $90 \mathrm{a}$ & $89 \mathrm{~b}$ & $90 \mathrm{a}$ & $92 \mathrm{a}$ & $91 \mathrm{a}$ \\
\hline IPR Taquari & $72 b$ & $90 \mathrm{a}$ & $88 \mathrm{~b}$ & $92 \mathrm{a}$ & $90 \mathrm{~b}$ & $92 \mathrm{a}$ \\
\hline Safira & $77 \mathrm{~b}$ & $92 \mathrm{a}$ & $90 \mathrm{a}$ & $90 \mathrm{a}$ & $92 \mathrm{a}$ & $92 \mathrm{a}$ \\
\hline Quartzo & $74 \mathrm{~b}$ & $94 \mathrm{a}$ & $92 \mathrm{a}$ & $93 \mathrm{a}$ & $92 \mathrm{a}$ & $94 \mathrm{a}$ \\
\hline $\mathrm{CV}(\%)$ & 5.87 & 5.25 & 4.06 & 3.58 & 3.11 & 4.18 \\
\hline
\end{tabular}

Averages followed by the same letter on the column do not differ among themselves by Scoot-Knott test $(\mathrm{p} \leq 0.01)$.

Table 3. Percentage of normal seedlings obtained from recently harvested seeds, with no treatment to overcome dormancy and with pre-chilling at $5-10{ }^{\circ} \mathrm{C}$ for 3 and 5 days of various wheat genotypes.

\begin{tabular}{|c|c|c|c|}
\hline \multirow{3}{*}{ Genotypes } & \multicolumn{3}{|c|}{$\begin{array}{l}\text { Percentage of normal seedlings } \\
\text { (recently harvested seeds) }\end{array}$} \\
\hline & \multirow{2}{*}{$\begin{array}{l}\text { Without } \\
\text { treatment }\end{array}$} & \multicolumn{2}{|c|}{$\begin{array}{l}\text { With pre-chilling } \\
\text { at } 5-10^{\circ} \mathrm{C}\end{array}$} \\
\hline & & 3 days & 5 days \\
\hline & \multicolumn{3}{|c|}{--------------- \% ------------- } \\
\hline BRS Tangará & $81 \mathrm{a}$ & $85 \mathrm{~b}$ & $85 \mathrm{~b}$ \\
\hline Catuará & $83 \mathrm{a}$ & $85 \mathrm{~b}$ & $85 \mathrm{~b}$ \\
\hline CD 108 & $77 \mathrm{~b}$ & $82 \mathrm{~b}$ & $82 \mathrm{~b}$ \\
\hline CD 116 & $84 \mathrm{a}$ & $89 \mathrm{a}$ & $88 \mathrm{a}$ \\
\hline CD 150 & $81 \mathrm{a}$ & $84 \mathrm{~b}$ & $84 \mathrm{~b}$ \\
\hline Guamirim & $83 \mathrm{a}$ & $88 \mathrm{a}$ & $87 \mathrm{a}$ \\
\hline Pardela & $85 \mathrm{a}$ & $88 \mathrm{a}$ & $88 \mathrm{a}$ \\
\hline Frontana & $76 \mathrm{~b}$ & 89 a & $90 \mathrm{a}$ \\
\hline IPR Taquari & $72 \mathrm{~b}$ & $90 \mathrm{a}$ & $90 \mathrm{a}$ \\
\hline Safira & $77 \mathrm{~b}$ & $91 \mathrm{a}$ & $90 \mathrm{a}$ \\
\hline Quartzo & $74 \mathrm{~b}$ & $91 \mathrm{a}$ & $91 \mathrm{a}$ \\
\hline C.V. $(\%)$ & 5.87 & 3.81 & 3.57 \\
\hline
\end{tabular}

Averages followed by the same letter on the column do not differ among themselves by Scoot-Knott test $(\mathrm{p} \leq 0.01)$.
Table 4. Percentage of dormant wheat seeds with no treatment to overcome dormancy and with prechilling at $5-10{ }^{\circ} \mathrm{C}$ for 3 and 5 days of various genotypes, obtained right after seed harvesting.

\begin{tabular}{lccc}
\hline & \multicolumn{3}{c}{$\begin{array}{c}\text { Dormant seeds right } \\
\text { after harvesting }\end{array}$} \\
\cline { 2 - 4 } Genotypes & $\begin{array}{c}\text { Without } \\
\text { treatment }\end{array}$ & \multicolumn{2}{c}{ at 5-10 ${ }^{\circ} \mathrm{C}$} \\
\cline { 2 - 4 } \cline { 2 - 3 } BRS Tangará & & 3 days & 5 days \\
\hline Catuará & $4 \mathrm{a}$ & $0 \mathrm{~b}$ & $0 \mathrm{~b}$ \\
CD 108 & $2 \mathrm{a}$ & $0 \mathrm{~b}$ & $0 \mathrm{~b}$ \\
CD 116 & $5 \mathrm{a}$ & $0 \mathrm{~b}$ & $0 \mathrm{~b}$ \\
CD 150 & $6 \mathrm{a}$ & $1 \mathrm{~b}$ & $1 \mathrm{~b}$ \\
Guamirim & $3 \mathrm{a}$ & $0 \mathrm{~b}$ & $0 \mathrm{~b}$ \\
Pardela & $5 \mathrm{a}$ & $1 \mathrm{~b}$ & $1 \mathrm{~b}$ \\
Frontana & $3 \mathrm{a}$ & $0 \mathrm{~b}$ & $0 \mathrm{~b}$ \\
IPR Taquari & $15 \mathrm{a}$ & $1 \mathrm{~b}$ & $1 \mathrm{~b}$ \\
Safira & $17 \mathrm{a}$ & $1 \mathrm{~b}$ & $1 \mathrm{~b}$ \\
Quartzo & $16 \mathrm{a}$ & $2 \mathrm{~b}$ & $2 \mathrm{~b}$ \\
\hline Avera & $18 \mathrm{a}$ & $1 \mathrm{~b}$ & $1 \mathrm{~b}$ \\
\hline
\end{tabular}

Averages followed by the same letter on the line do not differ among themselves by Scoot-Knott test $(\mathrm{p} \leq 0.01)$. 
After 30 days of storage, evaluations were repeated in order to quantify the percentage of dormant seeds (Table 5), proceeding to the germination evaluation without adopting any method to overcome dormancy. A significant reduction was noticed in the percentage of dormant seeds in the tested genotypes, which is probably associated to the hormonal balance between germination promoters and inhibitors, such as gibberellin and abscisic acid (Bojovic, 2010; Tunes et al., 2011; Taiz and Zeiger, 2013; Liu et al., 2013; Gao and Ayele, 2014; Marques et al., 2014; Marcos-Filho, 2015). When gibberellin is in higher concentrations than abscisic acid and the environment is favorable to the germination process, germination will occur.

The percentage of dormant seeds after 30 days of storage (Table 5) was also analyzed after seeds were submitted to a pre-chilling period of three and five days. It is possible to deduce that there are no differences in the number of dormant seeds for both methods.

Table 5. Percentage of dormant wheat seeds with no treatment to overcome dormancy and with prechilling at $5-10{ }^{\circ} \mathrm{C}$ for 3 and 5 days of various genotypes, obtained after 1 and 6 months of seed storage.

\begin{tabular}{|c|c|c|c|}
\hline \multirow{3}{*}{ Genotypes } & \multicolumn{3}{|c|}{ Dormant seeds } \\
\hline & \multicolumn{3}{|c|}{ After 30 days of storage } \\
\hline & $\begin{array}{l}\text { Without } \\
\text { treatment }\end{array}$ & $\begin{array}{l}\text { Pre-chilling } \\
\text { for } 3 \text { days }\end{array}$ & $\begin{array}{l}\text { Pre-chilling } \\
\text { for } 5 \text { days }\end{array}$ \\
\hline & \multicolumn{3}{|c|}{ 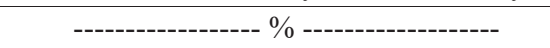 } \\
\hline BRS Tangará & $1 \mathrm{a}$ & $0 \mathrm{~b}$ & $0 \mathrm{~b}$ \\
\hline Catuará & 0 & 0 & 0 \\
\hline CD 108 & 0 & 0 & 0 \\
\hline CD 116 & $2 \mathrm{a}$ & $1 \mathrm{a}$ & $1 \mathrm{a}$ \\
\hline CD 150 & $1 \mathrm{a}$ & $1 \mathrm{a}$ & $0 \mathrm{~b}$ \\
\hline Guamirim & $1 \mathrm{a}$ & $0 \mathrm{~b}$ & $0 \mathrm{~b}$ \\
\hline Pardela & $1 \mathrm{a}$ & $0 \mathrm{~b}$ & $0 \mathrm{~b}$ \\
\hline Frontana & $1 \mathrm{a}$ & $0 \mathrm{~b}$ & $0 \mathrm{~b}$ \\
\hline IPR Taquari & $1 \mathrm{a}$ & $0 \mathrm{~b}$ & $0 \mathrm{~b}$ \\
\hline Safira & $2 \mathrm{a}$ & $1 \mathrm{a}$ & $1 \mathrm{a}$ \\
\hline Quartzo & $2 \mathrm{a}$ & $1 \mathrm{a}$ & $0 \mathrm{~b}$ \\
\hline \multirow[b]{2}{*}{ Genotypes } & \multicolumn{3}{|c|}{ After 180 days of storage } \\
\hline & $\begin{array}{l}\text { Without } \\
\text { treatment }\end{array}$ & $\begin{array}{l}\text { Pre-chilling } \\
\text { for } 3 \text { days }\end{array}$ & $\begin{array}{l}\text { Pre-chilling } \\
\text { for } 5 \text { days }\end{array}$ \\
\hline $\begin{array}{l}\text { All evaluated } \\
\text { genotypes }\end{array}$ & 0 & 0 & 0 \\
\hline
\end{tabular}

Averages followed by the same letter on the line do not differ among themselves by Scoot-Knott test $(\mathrm{p} \leq 0.01)$.

*Values that were equal to zero were not statistically analyzed.

According to Belderock (1976), during the period of wheat seed formation, more precisely during reserve accumulation and after physiological maturity, temperatures significantly influence dormancy control in seeds; this was also observed in rice seeds (Marques et al., 2014). During seed formation, the exposure of plants to low temperatures induces dormancy, since a reduced temperature itself is essential to overcome dormancy after physiological maturity (Reddy et al., 1985).

Since the storage conditions of seeds require lower temperatures to maintain their physiological and sanitary quality, it is expected that this low temperature induces the overcoming of seed dormancy. Seeds used in this research were stored in an environment with $14{ }^{\circ} \mathrm{C}$ temperature and $60 \%$ relative air humidity, during all experiment period. Under these conditions, it was observed that wheat seeds stored for 180 days (Table 5) did not present dormant seeds.

The adoption of simple and effective practices to make the germination evaluation of seeds quicker is an interesting and desirable technique for producing companies. Analyzing all information, it is possible to observe that dormancy is common in most tested wheat genotypes, some with higher intensity than others. On one hand, this dormancy is desired because it avoids viviparity, which brings damages to seed and grain producers (Franco et al., 2009; Tunes et al., 2011; Gavazza et al., 2012; Gao and Ayele, 2014); on the other hand, there are also companies that need to obtain, in a simple and effective way, the germination percentage of recently harvested seeds, in order to make decisions on the allocation of lots. In this sense, a two-day reduction in the process required to overcome dormancy makes the system more agile, as well as increasing the operational capacity of laboratories.

\section{Conclusions}

There is effectiveness in overcoming wheat seed dormancy by adopting the procedure of pre-chilling between 5 and $10{ }^{\circ} \mathrm{C}$ for three days.

\section{References}

BELDEROCK, B. Changes in the seed coat of wheat kernels during dormancy and after-ripening. Cereal Research Communications, v.4, p.165-171, 1976. http://www.scielo.br/scielo .php?script=sci nlinks\&ref=000095\&pid=S0101-3122200900020002900004\&lng=pt

BOJOVIC, B. The effects of temperature, length of storage and plant growth regulators on germination of wheat (Triticum aestivum L.) and triticale seeds. Biotechnology \& Biotechnological Equipment, v.24, n.2, p.1849-1853, 2010. http://www.tandfonline.com/doi/abs/10.2478/V10133-010-0027-1

BRASIL. Ministério da Agricultura, Pecuária e Abastecimento. Regras para análise de sementes. Ministério da Agricultura, Pecuária e Abastecimento. Secretaria de Defesa Agropecuária. Brasília, DF: MAPA/ACS, 2009. 395p. http://www.agricultura.gov.br/arq_editor/file/2946_regras_analise sementes.pdf 
CARVALHO, T.C.; KRZYZANOWSKI, F.C.; OHLSON, O.C.; PANOBIANCO, M. Improved assessment of wheat seeds vigor. Ciência e Agrotecnologia, v.36, n.6, p.608-614, 2012. http://www.scielo.br/scielo. php?script $=$ sci_arttext\&pid=S1413-70542012000600002

CONAB. Companhia Nacional de Abastecimento. Perspectivas para a agropecuária. http://www.conab.gov.br. Accessed on : Jan. 31 2016.

ELIAS, S.; GARAY, A.; GATCH, E. Seed quality testing and certification: resources useful in organic seed production. Organic Seed Resource Guide, v.1, p.1-5, 2015. http://articles.extension.org/pages/18331/seed-qualitytesting-and-certification:-resources-useful-in-organic-seed-production

FRANCO, F.A.; PINTO, R.J.B.; SCAPIM, C.A.; SCHUSTER, I.; VIGANO, J.; MARCHIORO, V.S.; BRACCINI, A.L. Pré-esfriamento para superação da dormência de sementes de trigo colhidas na época da maturidade. Revista Brasileira de Sementes, v.31, n.2, p.245-252, 2009. http://www.scielo.br/ scielo.php?script=sci_arttext\&pid=S0101-31222009000200029

GAO, F.; AYELE, B.T. Functional genomics of seed dormancy in wheat: advances and prospects. Plant Science, v.5, p.1-11, 2014. http://www.ncbi. nlm.nih.gov/pubmed/25309557

GAVAZZA, M.I.A.; BASSOI, M.C.; CARVALHO, T.C.; BESPALHOK FILHO, J.C.; PANOBIANCO, M. Methods for assessment of preharvest sprouting in wheat cultivars. Pesquisa Agropecuária Brasileira, v.47, n.7, p.928-933, 2012. http://www.scielo.br/scielo.php?script=sci arttext\&pid=S0100-204X2012000700008

GU, X.Y.; ZHANG, L.; GLOVER, K. D.; CHU, C.; XU, S. S.; FARIS, J. D.; FRIESEN, T. L.; IBRAHIM, A. Genetic variation of seed dormancy in synthetic hexaploid wheat-derived populations. Crop Science, v.50, p.1318-1324, 2010. https://www.researchgate.net/publication/231399840_Genetic_Variation_of_ Seed Dormancy in Synthetic Hexaploid Wheat-Derived Populations

KATAOKA, V.Y.; CARVALHO, M.L.M.; OLIVEIRA, M.S.; CALDEIRA, C.M. Validação de metodologia para o teste de germinação em sementes de nabo forrageiro (Raphanus sativus L. var. oleiferus). Revista Brasileira de Sementes, v.33, n.1 p.69-79, 2011. http://www.scielo.br/scielo. php?script=sci_arttext\&pid=S0101-31222011000100008

KISS, I. Significance of wheat production in world economy and position of hungary in it. Research in Agricultural \& Applied Economics, v.5, p.1-2, 2011. http://ageconsearch.umn.edu/handle/104650
LIU, A.; GAO, F.; KANNO, Y.; JORDAN, M.C.; KAMIYA, Y.; SEO, M.; AYELE, B.T. Regulation of wheat seed dormancy by after-ripening is mediated by specific transcriptional switches that induce changes in seed hormone metabolism and signaling. Plos one, v.8, n.2, p.1-18, 2013. http:// www.ncbi.nlm.nih.gov/pubmed/23437172

MARCOS-FILHO, J. Fisiologia de sementes de plantas cultivadas. Londrina: ABRATES, 2015. 659p.

MARQUES, E.R.; ARAÚJO, R.F.; ARAÚJO, E.F.; MARTINS FILHO, S.; SOARES, P.C.; MENDONÇA, E.M. Dormancy and enzymatic activity of rice cultivars seeds stored in different environments. Journal of Seed Science, v.36, n.4, p.435-442, 2014. http://www.scielo.br/scielo.php?script=sci_ arttext\&pid=S2317-15372014000400008

NONOKAGI, H. Seed dormancy and germination-emerging mechanisms and new hypotheses. Frontiers in Plant Science, v.5, p.1-14, 2014. http:// www.ncbi.nlm.nih.gov/pubmed/24904627

PUNDER, K.; PRUIMBOOM, L. The dietary intake of wheat and other cereal grains and their role in inflammation. Nutrients, v.5, n.3, p.771-787, 2013. http://www.mdpi.com/2072-6643/5/3/771

REDDY, L.V.; METZGER, R.J.; CHING, T.M. Effect of temperature on seed dormancy of wheat. Crop Science, v.25, p.455-458, 1985. https://dl.sciencesocieties.org/publications/cs/abstracts/25/3/ CS0250030455? access $=0$ \&view $=$ pdf

SILVA, F. A. S. Sistema de Assistência Estatística - ASSISTAT versão 7.7 beta. Departamento de Engenharia Agrícola (DEAG) do CTRN da Universidade Federal de Campina Grande - UFCG, Campina Grande - PB, 2016. <http://www.assistat.com/>. Accessed on Jan. $10^{\text {th }}, 2016$.

TAIZ, L.; ZEIGER, E. Fisiologia Vegetal, $5^{\mathrm{a}}$ edição, Porto Alegre: Artmed Editora, 2013. 918p

TUNES, L.M.; PEDROSO, D.C.; CONCEIÇÃO, G.M.; BARBIERI, A.P.P.; BARROS, A.C.S.A.; MUNIZ, M.F.B.; MENEZES, N.L. Tratamentos térmicos e químicos em sementes de trigo. Interciência, v.36, n.10, p.746751, 2011. http://www.redalyc.org/pdf/339/33921449007.pdf 